\title{
Yürüme biyomekaniği
}

\section{Biomechanics of the gait}

\author{
Ali Şeker ${ }^{1}$, Mehmet Ali Talmaç², ilker Sarıkaya ${ }^{3}$ \\ 1 İstanbul Medipol Üniversitesi Tıp Fakültesi, Ortopedi ve Travmatoloji Anabilim Dalı, İstanbul \\ ${ }^{2}$ Şişli Etfal Eğitim ve Araştırma Hastanesi, Ortopedi ve Travmatoloji Kliniği, İstanbul \\ ${ }^{3}$ Çocuk Ortopedi Kliniği, İstanbul
}

Yürümenin amacı; vücudu istenilen hızda ve doğrultuda, farklı yönlerde hareket ettirmektir. Bu işlem sırasında canIı; ilgili uzuvlarındaki eklemler, kaslar, tendon ve bağları belirgin bir şekilde kullanır. Vücut ağırlık merkezi, yürüme esnasında dikey düzlemde yukarı-aşağı, yatay düzlemde ise her iki yana hareket eder. Bu hareketlerin birleştirilmesi ile birleşik hareket paterni oluşur ve "sekiz" rakamına benzer bir şekil gözlemlenir. Yürüme esnasında ağırlık merkezinin dikey ve yatay düzlemde sapmalarını azaltan hareketler (belirteçler) oluşur. Bu hareketlerin amacı yürüyüşün verimli ve akıcı olmasını sağlamak, ağırlık merkezinin yatay ve dikey düzlemlerdeki sapmalarını azaltmak, enerji tüketimini azaltmak ve daha zarif bir yürüyüş elde etmektir. Bu belirteçler pelvik rotasyon ve tilt, duruş fazı diz fleksiyonu, ayak bileği ve ayak mekanizmaları, gövdenin lateral yer değiştirmesi, subtalar eklem inversiyon-eversiyonu, gövdenin ön-arka ve lateral fleksiyonlarıdır. "Dinamik yürüme" düşüncesine göre ise yürüyüş esnasında gövde tek bacak destek döneminde ters sarkaç, çift bacak destek döneminde sarkaç gibi hareket eder. Yürüme esnasında üstlendikleri göreve göre vücut lökomotor ve yolcu birim olmak üzere iki parçaya ayrılabilir. Lökomotor birim; ilerlemeyi sağlar, dikey dengeyi korur, darbenin oluşturduğu şoku azaltır ve enerji tasarrufu sağlar.

Anahtar sözcülkler: yürüme; biyomekanik ekanik, fiziğin bir alt dalı olup hareket ve harekete eğilim ile ilgilenir. Biyomekanik ise mekanik prensiplerinin ve mühendislik kurallarının biyolojik sistemlere uygulanmasıdır. İnsan vücuduna ve hareketlerine olan ilginin giderek artması ve biyolojiye daha uygun yeni implantların geliştirilebilmesi hedefi son dönemlerde giderek artan biyomekanik çalışmaların temel gerekçesini oluşturmaktadır. Bu amaçla insanın temel hareketlerinden olan yürüme ile ilgili pekçok çalışma yapılmış ve bu hareketin kinetik ve kinematik ayrıntıları birçok araştırmacı tarafından dikkatlice incelenmiştir. ${ }^{[1]}$
The aim of the gait is to transport the body in different directions with desired speed. During this action; joints, muscles, tendons and ligaments are used in related extremities. Center of gravity of the body moves up-down in vertical and both sides in horizontal planes. Combination of these movements form "eight figure". During walking, vertical and horizontal excursions of the center of gravity is decreased by "determinants". The aim of these movements are to increase the efficiency and smoothness of pathway of gait, decrease the vertical and lateral displacements of center of gravity, decrease the energy expenditure, and make gait more graceful. These determinants are pelvic rotation and tilt, knee flexion in stance phase, ankle and foot mechanisms, lateral displacement of the body, subtalar joint inversion-eversion, anteriorposterior and lateral flexions of the body. According to the "dynamic walking" principles, the body acts like inverted pendulum during single leg stance and like pendulum during double leg stance phases during walking. The body consists of locomotor and passenger units during gait cycles. Locomotor unit is responsible from progression, protection of vertical balance, shock absorption and decrease energy expenditure.

Key words: gait; biomechanics

Yürümenin amacı; vücudu istenilen hızda ve doğrultuda, farklı yönlerde hareket ettirmektir. ${ }^{[1,2]} \mathrm{Bu}$ işlem sırasında canlı; ilgili uzuvlarındaki eklemler, kaslar, tendon ve bağları belirgin bir şekilde kullanır. Bu nedenle yürümenin biyomekaniğinin incelenmesi aslında insan vücudu için alt ekstremitelere ait bütün yapıların ve yürümenin evrelerinin tek tek incelenmesini gerektirir. Bu konular diğer bölümlerde tartışılacaktır.

Yürüme siklusu, fazları ve destek noktalarına göre iki farklı şekilde evrelendirilir. Yürümenin duruş (stance) ve salınım (swing) olmak üzere iki fazı vardır (Şekil 1-3).

- Illetişim adresi: Yrd. Doç. Dr. Ali Şeker, İstanbul Medipol Üniversitesi Tıp Fakültesi, Ortopedi ve Travmatoloji Anabilim Dalı, İstanbul Tel: 0532 - 3262202 e-posta: aliseker@doctor.com

- Gelis tarihi: 23 Temmuz 2014 Kabul tarihi: 23 Temmuz 2014 


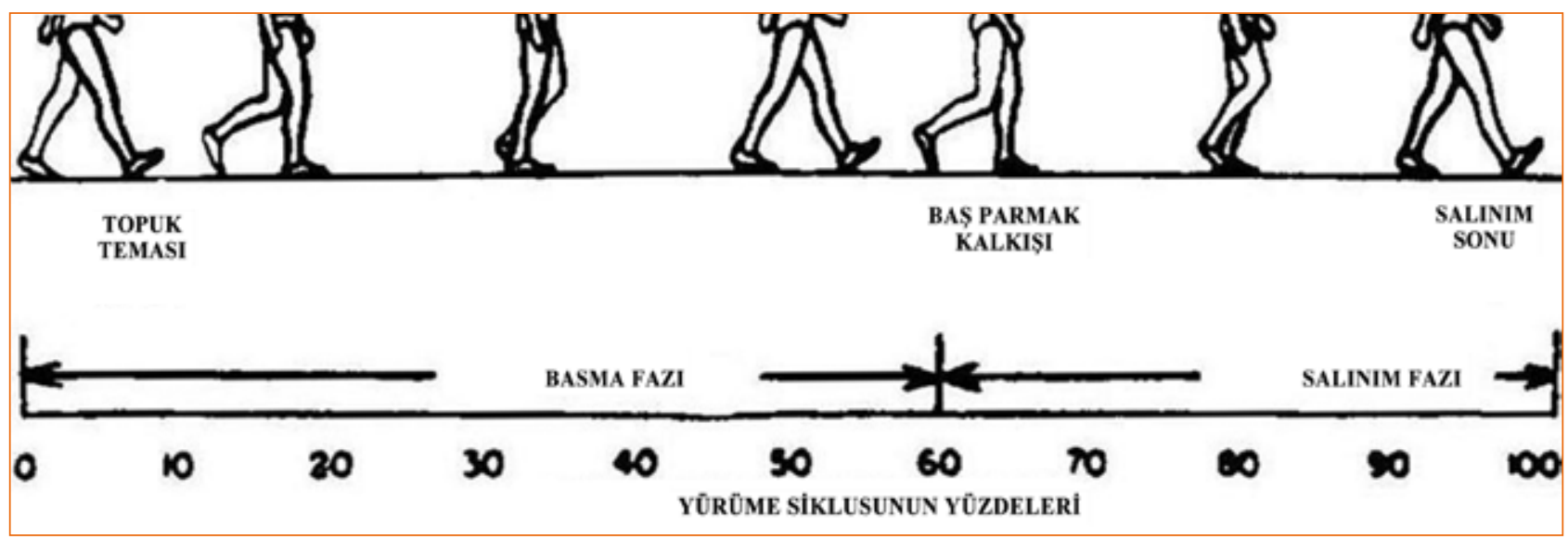

Şekil 1. Yürümenin fazları ve döngüdeki sürelerinin oranları.

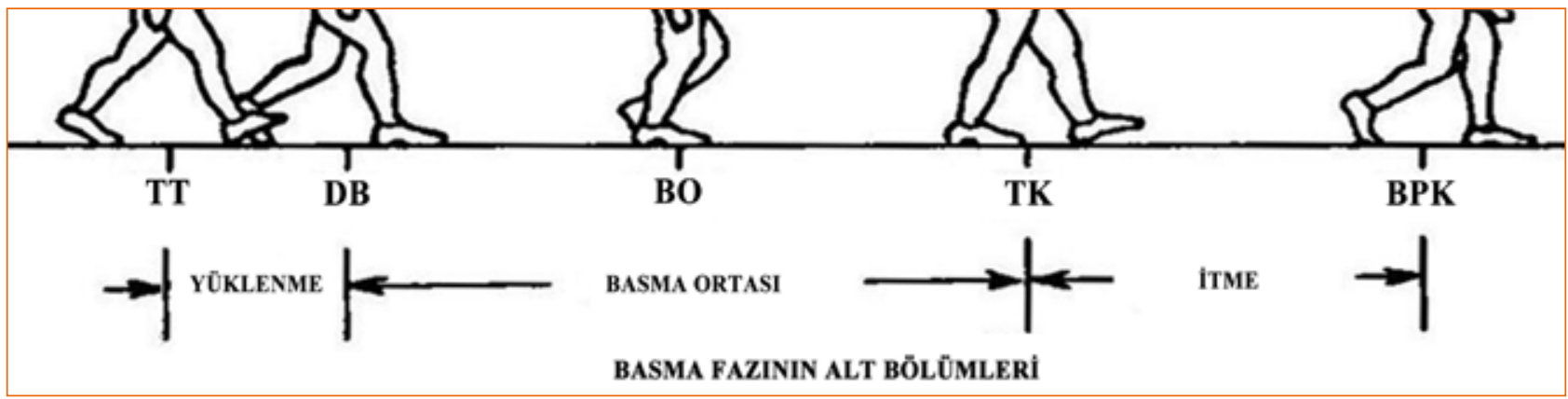

Şekil 2. Yürümenin basma fazının alt bölümleri. TT: Topuk teması, DB: Düz basma, BO: Basma ortası, TK: Topuk kalkışı, BPK: Baş parmak kalkışı.

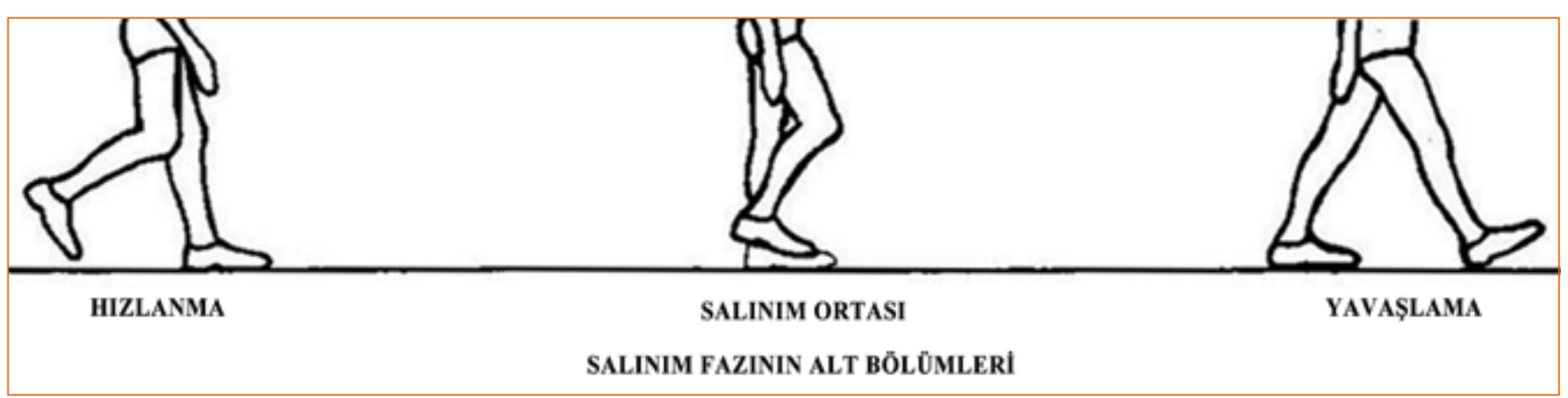

Şekil 3. Yürümenin salınım fazının alt bölümleri.

Destek noktaları göz önüne alındığında ise yürüme siklusu tek destek (single support) ve çift destek (double support) olmak üzere iki evreye ayrılır. Tek destekte sadece tek ayak, çift destekte ise her iki ayak zemin ile temas eder. Hızın artması ile çift destek evresinin oranı azalır, tek destek evresinin oranı ise artar. Hızın daha da artması ile çift destek evresi tamamen ortadan kalkar ve "koşma" olarak tanımlanan hareket siklusu oluşur.

Bu bilgilerin yanında "vücut ağırlık merkezi" de önemli bir kavram olarak vurgulanmalıdır. Bu merkez, iki kalça arasındaki mesafenin ortasında ve ikinci sakral vertebranın hemen önünde yer alır. Vücut ağırlık merkezi, yürüme esnasında dikey düzlemde yukarıaşağı, yatay düzlemde ise her iki yana hareket eder. Bu hareketler her iki planda da yaklaşı $5 \mathrm{~cm}$ kadar bir mesafeyi kateder. Ağırlık merkezinin duruş ortası fazında en yüksek, çift destek evresinde en düşük seviyede olduğu bilinmektedir. Ancak ağırlık merkezinin duruş ortası fazdaki en yüksek olduğu seviye bile kişinin ayakta durduğu dönemle karşılaştırıldığında daha alçakta kalır. Bu durum yürüme esnasında ayakta durmaya oranla kişinin boyunun daha kısa olduğu anlamına gelir. Bu faz aynı zamanda yatay düzlemde 
en fazla değişimin olduğu dönemdir. Her iki plandaki hareketler düzlemsel olarak sinusoidal bir eğri oluşturur. ${ }^{[1-10]} \mathrm{Bu}$ hareketlerin birleştirilmesi ile birleşik hareket paterni oluşur ve "sekiz" rakamına benzer bir şekil gözlemlenir (Şekil 4).

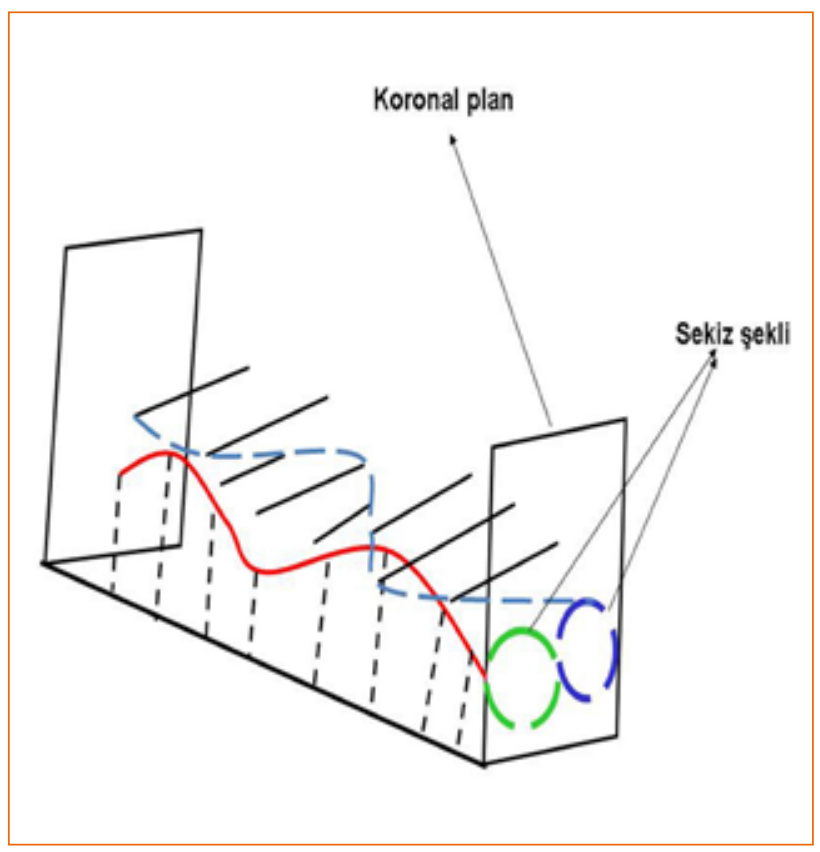

Şekil 4. Vücut ağırlık merkezinin dikey (kırmızı kesintisiz çizgi) ve yatay (mavi kesik çizgi) düzlemdeki hareketlerinin oluşturduğu eğriler ve bunların birleşiminden oluşan 8 şekli.
1953 yılında Saunders ve arkadaşları "Yürümenin belirteçleri - Gait Determinants/ D” kavramını ortaya atmışlardır. ${ }^{[3]}$ Burada belirteç olarak bahsedilenler; pelvis, kalça, diz ve ayak bileğinde olan ve ağırlık merkezinin dikey ve yatay düzlemde sapmalarını azaltarak yürüme esnasında harcanan enerjiyi düşüren hareketlerdir. Bu hareketlerin dört temel amacı vardır;

1) Yürüyüşün verimli ve akıcı olmasını sağlamak.

2) Ağırlık merkezinin yatay ve dikey düzlemlerdeki sapmalarını azaltmak.

3) Enerji tüketimini azaltmak.

4) Daha zarif bir yürüyüş elde etmek.

Altı belirteç vardır;

D1. Pelvik Rotasyon: Normal yürüyüşte pelvis ilerleme çizgisine göre salınım tarafındaki uzuv sağa ve sola doğru rotasyon yapar. Bu rotasyon her bir yönde ortalama $4^{\circ}$ ve toplamda yaklaşık $8^{\circ}$ kadardır. Bunun yanında kalçada duruş fazında iç ve dış rotasyon da olur. Dikey düzlemde pelvisin rotasyonu kalça fleksiyon ve ekstansiyonunu azaltır. Bu sayede kalça ekleminin yükselip alçalması yani ağırlık merkezindeki dikey planda değişme miktarı yaklaşık $0,9-1 \mathrm{~cm}$ kadar azaltılır (Şekil 5).

D2. Pelvik eğilme (tilt): Normal yürüyüşün salınım fazındaki uzuv tarafında pelvis aşağı doğru düşer. Eğilmenin büyüklüğü duruş fazındaki uzuv tarafındaki

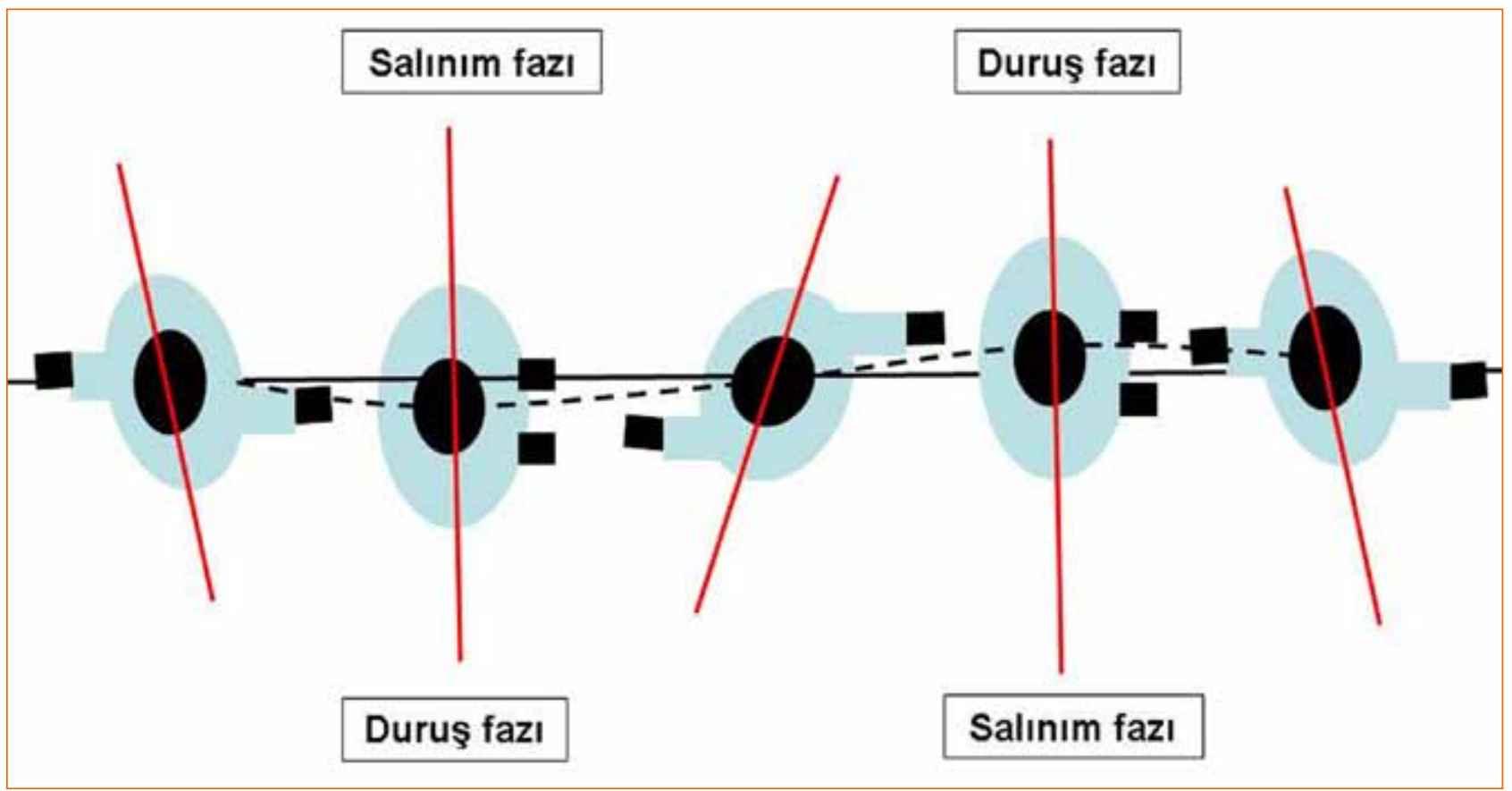

Şekil 5. Altı belirteç teorisinde D1- pelvik rotasyon (kırmızı çizgi) ve D6- gövdenin lateral yer değiştirmesi (kesik çizgi). 
kalça abduktorları tarafından kontrol edilir. Ön-arka planda oluşan bu eğilme mid-swing'de en fazladır. Pelviste aşağı doğru oluşan bu eğim açısal olarak ortalama $5^{\circ}$ kadardır. Aynı anda kalça ekleminde göreceli olarak duruş fazında adduksiyon, salınım fazında abduksiyon görülür. Bu sayede ağırlık merkezinde dikey planda olan değişiklik $0,3 \mathrm{~cm}$ azaltılır.

D3. Duruş fazında diz fleksiyonu: Normal yürüyüşün ilk temas anında diz $0-5^{\circ}$ kadar fleksiyondadır. Topuk teması ile $15-20^{\circ}$ 'lik ilk fleksiyon sapması olur. Bu sayede şok emilimi ve ağırlık merkezi değişiminin azaltılması amaçlanır. Böylece enerji tasarrufu sağlanır. Illerleyen süreçte diz tam ekstansiyona gelip daha sonra $10^{\circ}$ ikinci fleksiyon sapması olur.

D4. Ayak bileği mekanizması: Normal yürüyüşün duruş fazının erken döneminde ayağın yere ilk teması esnasında ayak bileği dorsifleksiyona alınır. Bu esnada diz tam ekstansiyondadır. Bacak boyu uzar ancak ağırlık merkezinin yüksekliği azalır.

D5. Ayak mekanizması: Duruş fazının geç dönemlerinde diz fleksiyona alınmaya başlanırken ayak plantar fleksiyona doğru ilerler ve bacak boyu uzun tutulmaya çalışııı. Böylece ağırlık merkezinin konumunda en az değişiklik olması amaçlanır.

D6. Gövdenin lateral yer değiştirmesi: Adım genişliğinin dar olması ağırlık merkezinin lateral yer değiştirmesini en az seviyede tutar. Dizin yürüme esnasında hafif valgusa gitmesi bu daralmanın korunması açısından önemlidir. Yürüme siklusunda duruş fazındaki uzuv tarafında pelvis yatay düzlemde dışa kayar. Burada amaç ağırlık merkezini duruş fazındaki tarafa yanaştırmak ve ona ait abduktorların salınım fazı tarafına doğru pelvik eğimi dengelemesini kolaylaştırmaktır (Şekil 5). Duruş ortası fazında lateral yer değiştirme yaklaşı $4,5 \mathrm{~cm}$ kadar olmaktadır. Buna yanıt olarak kalçanın göreceli olarak adduksiyona gitmesi de diz valgusu ile tolere edilerek değişim miktarı azaltılır.

Daha sonraları bu altı belirtece üç yeni belirteç daha eklenmiştir. Bunlar, sırasıyla;

\section{D7. Ayağın subtalar eklemden inversiyon-eversiyon-inversiyonu}

\section{D8. Gövdenin lateral fleksiyonu}

\section{D9. Gövdenin ön-arka fleksiyonu}

Ancak yapılan çalışmalarda, her ne kadar Saunders'in belirteçleri yürüyüş esnasında gerçekten oluşsa da, enerji tasarrufunda gerçekte vurgulandıkları kadar önemli olmadıkları iddia edilmektedir. ${ }^{[11-14]}$ Buna ek olarak ağırık merkezinin bu tarz düze yakın hareket yörüngesine sahip olmasının, kasların iş yükünü, ihtiyaç duyulan kuvvetin miktarını ve enerji maliyetini arttırdığı iddia edilmektedir. Kerrigan ve arkadaşları aslında sadece D5 belirtecinin ağılık merkezinin yüksekliğinin optimizasyonunda rol oynadığını göstermişlerdir. ${ }^{[12]} \mathrm{Bu}$ düşünceye sahip kişilerin destelediği "Dinamik yürüme düşüncesi" yürüme esnasında yapılan iş ve harcanan enerjiyi farklı şekilde açıklar. ${ }^{[4-5]} \mathrm{Bu}$ görüşe göre enerji maliyeti aslında ilerleme ve kontrol kadar önemli değildir. Kinetik, kinematik ve dinamik etkenlerin enerji maliyeti ve kontrol ile olan ilişkileri de düşünülmelidir. Baker ve arkadaşları ağırlık merkezinin yüksekliğinin düşürülmesinin, enerji maliyetinin optimizasyonuyla ilişkili olmadığını iddia etmekte; asıl önemli etkenin vücudun yerçekimsel ve kinetik enerji büyüklüklerinin ve fazların ilişkilerinin korunabilmesi olduğunu vurgulamaktadırlar. ${ }^{[15]}$

2000'li yılların başında kendilerini "Dinamik Yürüme Grubu" olarak adlandıran bir grup araştırmacı yürüyüşü "ters sarkaç" (inverted pendulum) modeli üzerinden açıklamaya çalıştılar. Buna göre yürüyüş esnasında gövde tek bacak destek döneminde ters sarkaç, çift bacak destek döneminde sarkaç gibi hareket eder. ${ }^{[16]} \mathrm{Bu}$ noktada ters sarkaç kavramını açıklamak gerekir: Bilindiği gibi sarkaç bir ip veya çubuğa bağlı bir kütleden oluşan sisteme verilen addır. Bu sistem destek noktasının altında yer alan ağırlık merkezi yer çekiminin etkisiyle hareketsiz durur. Herhangi bir kuvvetin etkisiyle periyodik hareket başlar. Ters sarkaçta ise destek noktası ağırlık merkezinin altında yer alır. Bu durumda yer çekimi sistemi durdurmak yerine hareket ettirme eğilimindedir (Şekil 6, 7). Yürümenin ters sarkaç modelinde, tek bacak destek döneminde durma fazındaki bacak ters sarkaç gibi davranır. Sarkacın avantajı mekanik enerjiyi koruması ve bir ark üzerinde hareket oluşturmak için mekanik işe ihtiyaç duymamasıdır. Mekanik enerji değiş-tokuşu ve tek bacak destek pozisyonunda bacak uzunluğundaki değişimin gözlenmesi, sarkaç benzeri davranış için güçlü bir endikasyondur. ${ }^{[17,18]}$ Ters sarkaç mekanik enerji değiş̧-tokuşunu öngörür. Buna göre, kinetik enerjideki herhangi bir değişiklik, kas tarafından mekanik iş oluşturulmasına gerek duymadan, buna karşı gelen yerçekimsel potansiyel enerji değişimi tarafından dengelenir. Bu iki tip enerji arasındaki dalgalanmalar, tek bacak destek evresinde duruş fazındaki uzuv tarafından az bir mekanik iş yaparak, birbirleriyle karşılıklı hareket ettiklerini doğrular. Kuo'ya göre, tek bacak destek dönemi ağırlık merkezini az iş ve kas gücüyle ("altı belirteç" teorisine oranla daha az bir miktarla) taşıyabilmek için ters sarkaç gibi davranır. ${ }^{[4]}$ Bu şekilde yürüyebilmek için adımdan adıma geçiş gerekmektedir. Bu geçişler duruş fazının evrelerine göre şu şekilde özetlenebilir (Şekil 8-10); 


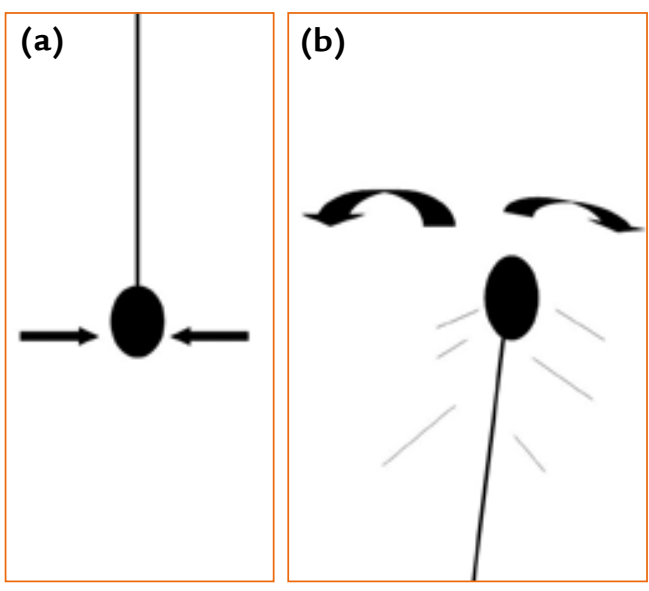

Şekil 6. a, b. Sarkaç (a) ve ters sarkaç (b) kavramları.

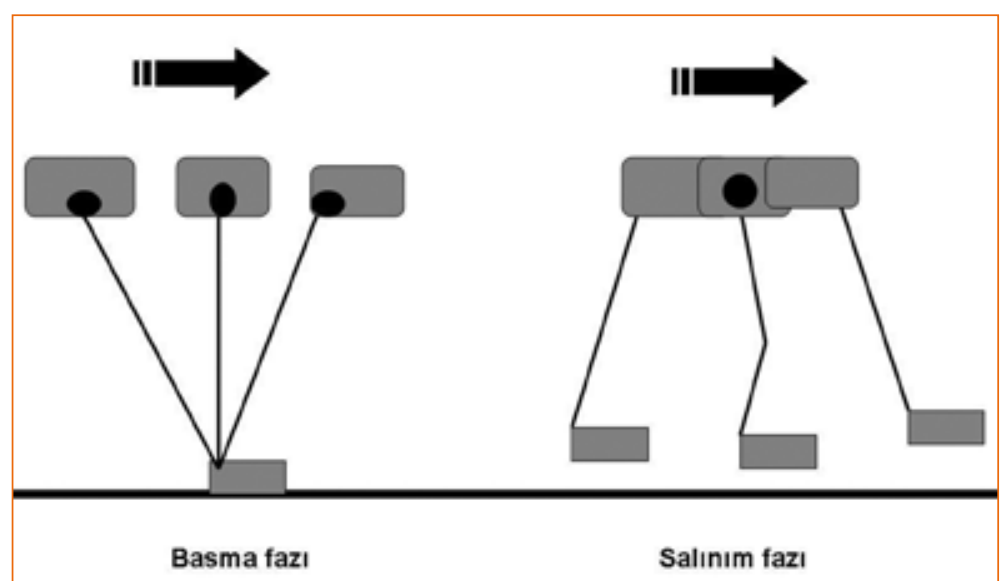

Şekil 7. Sarkaç kavramlarının yürüyüş̧e uyarlanışı. Salınım fazında sarkaç, basma fazında ters sarkaç modeli işlemektedir.

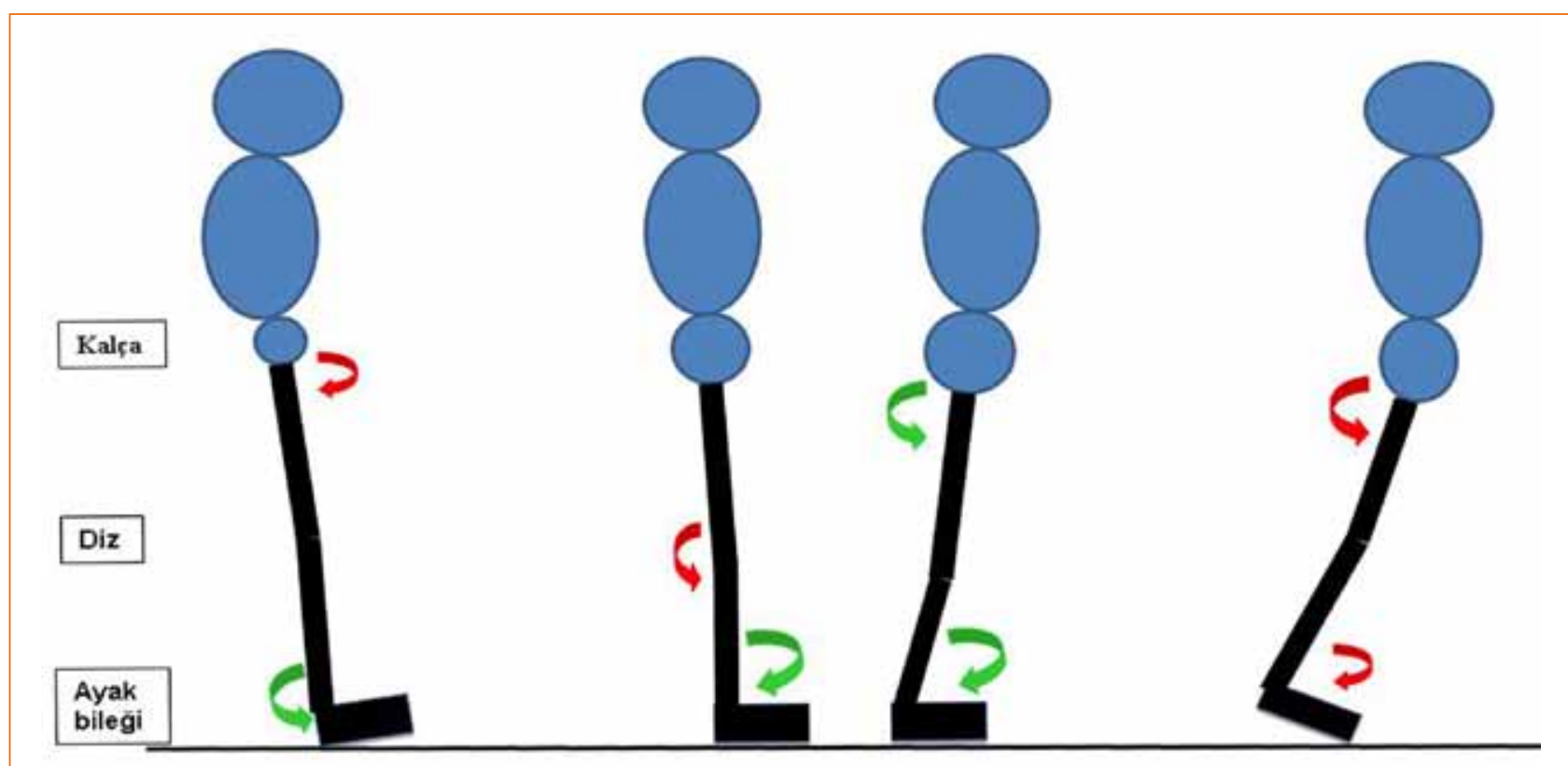

Şekil 8. Kuo'ya göre adım geçişleri ve iş yükü. Yeşil oklar negatif iş, kırmızı oklar pozitif işi temsil etmektedir. ${ }^{[4]}$

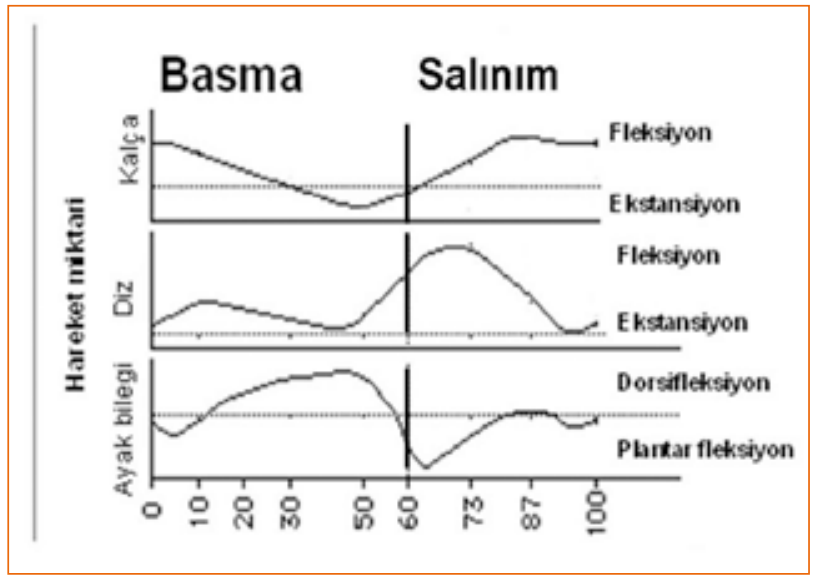

Şekil 9. Yürüme döngüsü ve alt birimlerinde kalça, diz ve ayak bileği eklemlerinin sagittal düzlemdeki hareketleri.

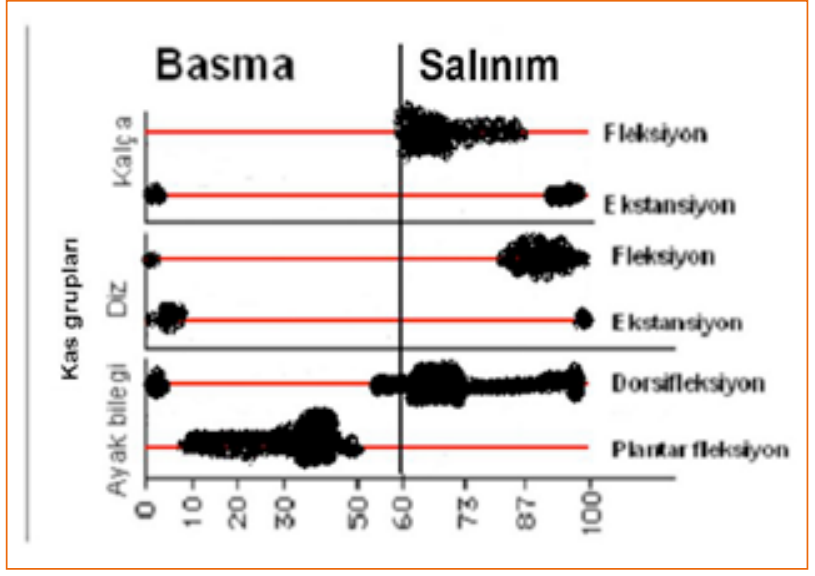

Şekil 10. Yürüme döngüsü ve alt birimlerinde kalça, diz ve ayak bileği eklemleri çevresinde kas gruplarının çalışma dönemleri. 
- Ayağın yere çarpmasından şok emilimi dönemine doğru gidildiğinde diz fleksiyona, ayak bileği ise plantar fleksiyona doğru gider. Duruş fazının bu erken döneminde kalça ve diz ekstansörleri, ayak dorsifleksörleri ana katılımcılardır.

- Şok emilimi döneminden yüklenme öncesine doğru gidildiğinde diz ekstansiyonda durur. Tibia sabit duran ayak bileği üzerinden kayar. Gluteus maksimus, gluteus medius, kuadriseps femoris ve soleus kasları, kalça ve dizin ekstansiyonunu, ayak bileğinin plantar fleksiyonunu sağlarlar.

- Yüklenme öncesinden itme (push off) dönemine doğru gidilirken diz hızlıca fleksiyona, ayak bileği plantarfleksiyona alınır. Iliopsoas, gastroknemius, sartorius ve grasilis bu dönemde en çok çalışan kas gruplarıdır.

Ağırlık merkezini arklar arasında yeniden yönlendirmek için iş gereklidir. Sondaki bacak tarafından pozitif iş, önde yer alan öncü pozisyondaki bacak tarafından ise negatif iş yapılır. Metabolik harcama ağılık merkezindeki yer değiştirmeye değil, adımlar arasındaki yeniden yönlendirmeye, iş hızı ve metabolik enerji harcaması ise adım uzunluğu ve genişliğine bağlıdır.

Yürüme esnasında vücut işlevsel olarak yolcu ve lökomotor birim olmak üzere ikiye ayrılır:

1) Yolcu birim: Baş, gövde ve kollardan oluşur ve lökomotor birim tarafından taşınır. Hareket esnasında kendisine ait duruşsal bütünlükten sorumludur. Ancak yürüyüş esnasındaki dizilimi lökomotor sistem içindeki kas hareketlerinin temel belirleyicisidir. Bu noktada baş ve gövdedeki kas hareketleri normal yürüyüş esnasında en az postüral değişiklikle omurganın nötral dizilimini sağlamayı amaçlar. Kolların sallanması ise aktif ve pasif alt evrelerden oluşur ancak normal yürüyüş için gerekli değildir. Yapılan çalışmalar bu hareketlerin kısıtlanmasının enerji tasarrufuna yol açmadığını göstermiştir. ${ }^{[19]}$

Yolcu birimi kütlesel olarak vücut ağırlı̆ıııın yaklaşık \%70'ini oluşturur. Bu birimin ağırlık merkezi 10. torasik omurganın hemen önünde yer alır. Bu durum kalça eklemlerinin yukarısında ortalama bir insan boyu düşünüldüğünde yaklaşık 33 santimetrelik uzun bir kaldıraç koluna denk gelir. Bu nedenle, yolcu biriminin dengesi alt ekstremitelerin anlık dizilimine oldukça bağlı kalır (Şekil 11). ${ }^{[20]}$

2) Lökomotor birim: Pelvis ve iki alt ekstremiteden oluşur. Lumbosakral, ikişer kalça, diz, ayak bileği ve subtalar eklemin yanında iki adet metatarsofalengeal eklemler bütünü olmak üzere toplam 11 eklemi içerir. Her uzva ait hareketin zamanlama ve büyüklüğü yaklaşık 57 kasın kontrolü altındadır. Kemiksel birimler (pelvis, uyluk, kaval, ayak ve parmak kemikleri) kaldıraç kolu görevi görür. ${ }^{[19]}$ Birçok alt gruba sahip bir birim olarak alt ekstremitelerden herbiri yolcu biriminin desteklenmesi ve ileri taşınmasında sorumluluk alır. Daha sonrasında ise hızla yeni bir pozisyon için

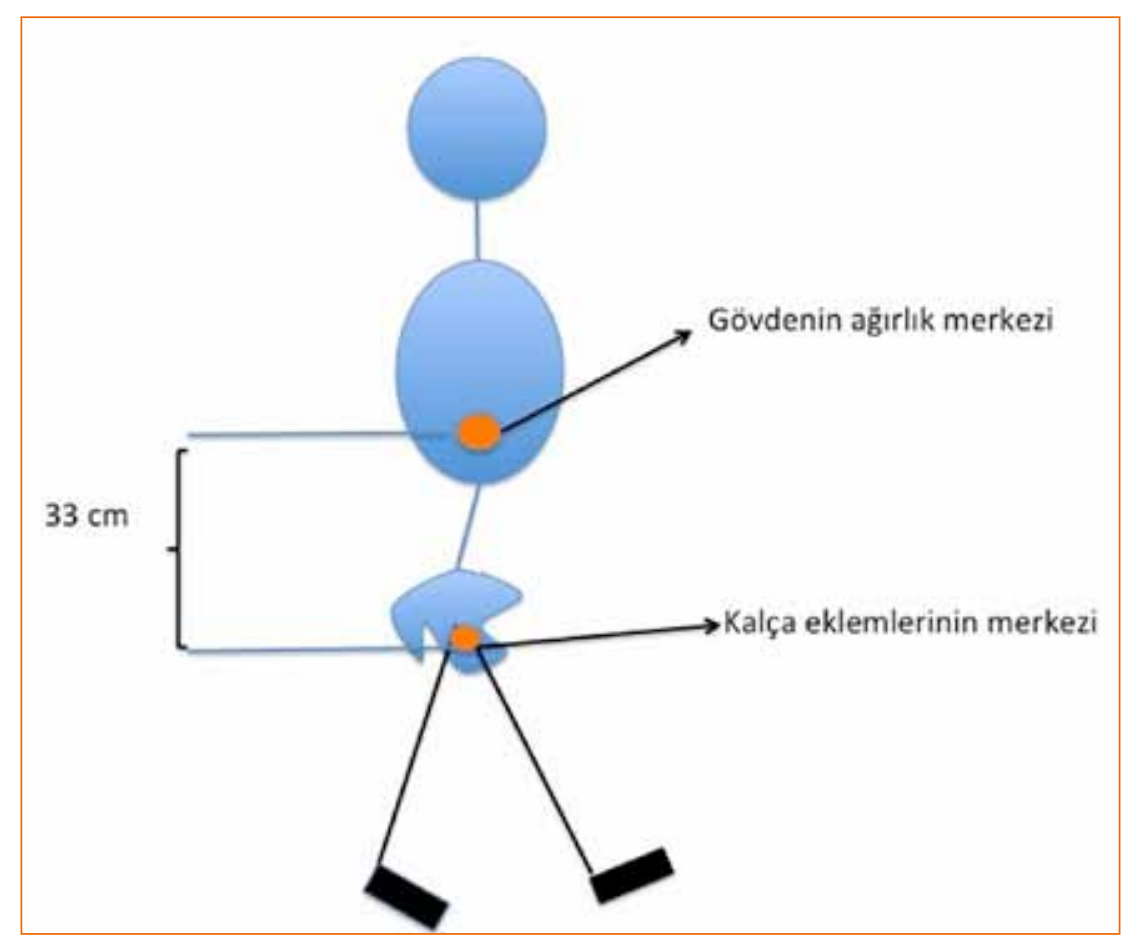

Şekil 11. Gövdenin ağırlık merkezi kalça eklemlerinden ortalama $33 \mathrm{~cm}$ uzakta yer alır. Vücudun yolcu birimi (mavi renkliler) ve lökomotor birimi (siyah renkliler). 
salınıma geçer ve tekrar destek oluşturmak için hazırlanır. Bu noktada, pelvis iki alt ekstremite arasında bağlantıyı sağlamasının yanında, kalça eklemleri üzerinde ilerleyen yolcu biriminin alt parçasını da oluşturur.

Lökomotor birimden bahsetmişken, kas gruplarının çalışma ilkelerinden de bahsetmek gerekir. Yürüme için, momentum kadar kasların kasılması da gereklidir. íki tip kas kasılması vardır: ${ }^{[21]}$

a) Konsantrik kasılma: Bu tip kasılmada kas boyu kısalır ve enerji üretir. Vücudu ivmelendirir. Basma fazının sonunda iki büyük konsantrik kasılma olur. Gastrosoleus kasılarak topuğu zeminden kaldırır ve push off u sağlar. Iliopsoas ise kasılarak kalçayı fleksiyona getirip basma fazının sonundaki bacağı zeminden kaldırır. Bu iki kas grubu yürümenin iki temel ivmelendiricisidir. Salınım fazında ise tibialis anterior kası konsantrik olarak kasılır, ayak bileğine dorsifleksiyon yaptırır ve salınımdaki ayağı zeminden kaldırır.

b) Eksentrik kasılma: Bu tip kasılmada kas boyu uzar. Yürüme esnasında eklem hareketlerini yavaşlatır ve stabilize eder. Böylece enerji ihtiyacını azaltır. Yürümenin ilk temas fazında, tibialis anterior eksentrik olarak kasılarak ayağın yere yumuşak temasını ve vücut ağırlığının kademeli olarak aktarılmasını sağlar. Gastrosoleus, basma fazının ortasında eksentrik olarak kasılarak tibianin ilerleyiş̧i sırasında ayak bileği dorsifleksiyonunu kontrol eder. Aksi durumda zayıf bir itme ve kalkaneus yürüyüşü oluşur. Bunun yanında kalça abduktorları da basma fazında yükün kabullenilmesi esnasında eksentrik olarak kasılarak pelvisin düşmesini engeller.

Lökomotor birim vücudu istenilen yere taşırken, bu esnada yük taşıyan uzuv dört görevi yerine getirir: 1) itici kuvvet oluşturarak ilerleme sağlamak; 2) dikey dengeyi korumak; 3) adım başlangıcındaki zemine olan darbenin oluşturduğu şoku azaltmak; 4) enerji tasarrufu sağlamak amacıyla kasları en az düzeyde çalıştırmak. Bunların herbiri belirli hareket tarzlarına bağlı olarak gerçekleştirilmekte ve gövde ile alt ekstremiteler arasındaki karmaşık ilişkileri ifade etmektedir.

Şimdi bu görevleri tek tek inceleyelim:

1) ilerleme: Bu görevin yerine getirilebilmesi için gövdenin öne doğru düşürülmesi temel itici kuwvet olarak kullanılır. Bu esnada topuk, ayak bileği ve ön ayak bir beşik gibi görev yaparak diz ekstansiyonda tutulurken gövdenin ilerlemesini sağlar. Karşı uzvun ileri doğru salınımı ikinci bir güç olarak kullanılır. Bu kuvvet, uzvun ileri doğru ivmelendirici şekilde ilerletilmesi ve gövdeye göre daha önde dizilimi sonucu oluşur. Bu durum özellikle duruş ortası fazında çok önemlidir.

İlerleme esnasında destek uzvun ayak bileği kontrolü, kişinin duruş pozisyonuna bağlı olarak farklılıklar gösterebilir. Genel duruş pozisyonu olan ayak bileğinin hafif dorsifleksiyonu sırasında soleus kası kuvvetini azaltır ve tibia ileri doğru eğilir. Eğer dizler hiperekstansiyonda ve ayak bileği plantar fleksiyonda duruluyorsa, tibialis anterior ve diğer pretibial kaslar kasılarak tibiayı ileri doğru sürükler. Bunun yanında duruş pozisyonundaki dizilimden bağımsız olarak adım, gövdenin ileri doğru düşürülmesi ve destek uzva ait ayak bileğinin anterioruna yer değişitirilmesi ile başlar. Kalçanın fleksiyona, ayak bileğinin dorsifleksiyona getirilmesi, duruş dengesini bozarak öne doğru bir kuvvet oluşturur. Kalça fleksiyonunun hızlanması ivmelenmeyi de arttırır. [21-23] illeri doğru düşen gövde, salınımını bitiren karşı bacak tarafından yakalanır ve böylece ilerleme döngüsü başlar. Bu döngünün sağlanabilmesi, ayak ve ayak bileğinin beşik gibi görev yapması ve kalça ile dizin pasif ekstansiyonlarına bağlıdır. Bunun yanında, ilerleme sırasında gövde dengesinin sağlanmasında pelvisin stabilizasyonu da önemlidir. Salınım fazındaki uzuv ilerletilirken destek pozisyonundaki tarafta kalça abduktor kasları kasılarak pelvisi destekler ve vücut ağırlığına karşı yatay düzlemdeki dengeyi sağlar. Vücut ağırlığı ve kuvvetlerin uygulanma noktaları düşünüldüğünde, abduktor kasların vücut ağırlı̆ııın yaklaşık 2,7 katı kadar kuvvet uygulaması gerekir. ${ }^{[1]} \mathrm{Bu}$ dengenin bozulması Trandelenburg yürüyüşüne neden olur (Şekil 12).

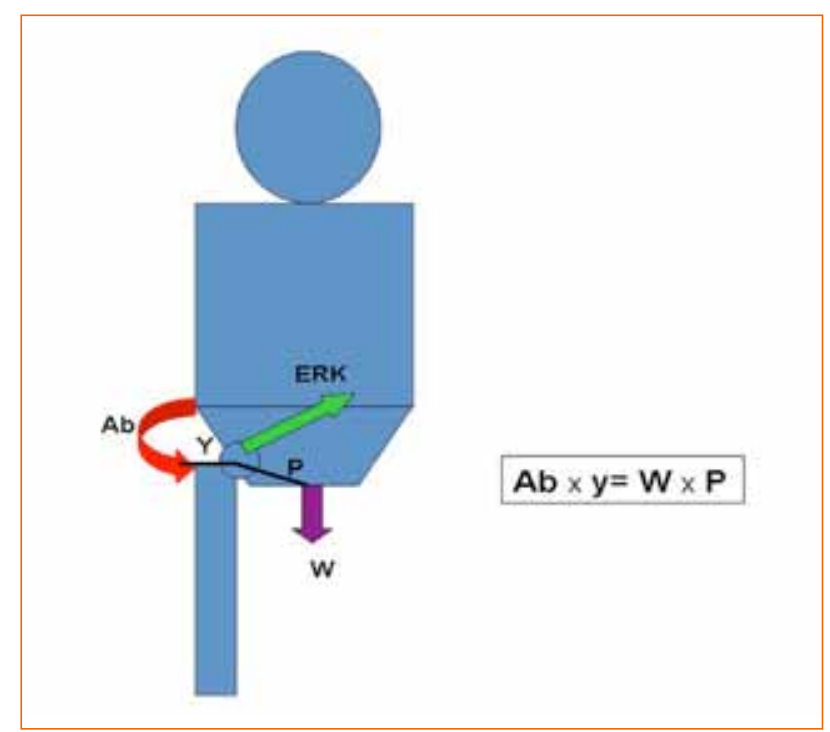

Şekil 12. Abduktor kas grubu (Ab), tek bacak destek döneminde pelvisin boşta kalan tarafa düşmesine engel olur. ERK = Eklem reaksiyon kuvveti. $\mathrm{W}=$ Vücudun yere basan kısmı dışındaki bölümlerinin ağırlığı sebebiyle oluşan vektör. $y=$ abduktor kas grubunun femura yapışma noktası ile femur başı merkezi arasındaki mesafe (abduktor kas grubu vektörü kolu). $\mathrm{P}=$ vücut ağırlık vektörünün etki noktası ile femur başı arasındaki mesafe (vücut ağırlık vektörü kuvvet kolu). 
Vücut ağırlığı duruş fazındaki uzva düşürüldüğünde, ileri düşme sonucu oluşan momentum topuk beşiği tarafindan korunur. ${ }^{[21]}$ Bu noktada, kalkaneal tuberositas zemin ile temas halindedir. Bu nokta ile ayak bileğinin merkezi arasındaki mesafe, dengesiz bir kaldıraç görevi görür. Pretibial kasların kasılması, kuadriseps kasının da femuru tibiaya bağlamasıyla alt ekstremitede ilerleyici bir moment oluşturur (Şekil 13).

Ön ayağın yere teması ile ayak bileğinin beşik görevi başlar. Bu esnada pasif ayak bileği dorsifleksiyonu ile tibianın ilerlemesi devam eder. Gövdeye ait vektör, ayak uzunluğu boyunca metatars başlarına doğru ilerler. Bu esnada soleus kası gastroknemius ile beraber çalışarak tibia ekstansiyonu için dengeleyici bir unsur oluşturur ve tibianin ilerlemesini yavaşlatır.

Gövde vektörü yuvarlak şekilli metatars başlarına denk geldiğinde, ön ayağın beşik görevi başlar ve topuk havalanır. Vücut ağırlığı ayak desteğinin daha ilerisine düştüğünde, ilerleme ivmelenir. Bu kuvvet, yürüme döngüsünün en kurvetli itici gücüdür. Pre-swing fazında gövde vektörünün metatars başlarından ve dizin merkezinden geçmesi ile diz ve ayak bileği için dengeleyici bir unsur kalmaz. Bu esnada vücut ağırlığı hızlıca diğer bacağa iletilir. Rezidüel olarak kalan gastrosoleus kas hareketi, metatarsofalengeal eklem üzerinden ayağa döndürme görevi yapar. Sonuç olarak, aynı anda diz ve ayak bileği fleksiyonu oluşur. Bu esnada adduktor kaslar da kalça fleksiyonuna yol açar. Bu sayede hızIı bir ilerleme momenti sağlanır. ${ }^{[19]}$ Salınım fazındaki bacaktaki kalça fleksiyonu ve diz ekstansiyonunun da eklenmesi ile öne doğru düşen gövde yakalanmaya hazır hale gelir ve ilerleme döngüsü tamamlanır.

2) Duruş stabilitesi: Stabilite, vücudun dizilimi ile eklemlerin kas hareketleri arasındaki işlevsel denge arasında sağlanır. Her vücut bölümü, zemine düşen ve zemin tarafindan da dengelenen bir eklem reaksiyon kuvveti (joint reaction force - JRF) oluşturur. Her kütlenin bir ağırlık merkezi vardır. Üst ekstremiteye ait ağırlık merkezi alt ekstremitede destek eklemle aynı düzlemde ise burada pasif stabilitenin olduğu kabul edilir.

Duruş dengesi üç durum tarafından belirlenir. Lökomotor ve yolcu sistemler arasındaki denge bunlardan ilkidir. Destek uzvun çok segmentli yapısı ve eklem yüzeylerinin yapısı, ikinci ve üçüncü unsurları oluşturur. Çift bacak destek döneminde gövdeye ait yük ikiye bölünürken, tek bacak destek döneminde yaklaşık \%30'luk bir kütle \%70'lik kısmı destekler. Bu noktada kas ve bağlara ait dengeleyici kurvetler devreye girer. Üst ekstremiteye ait ağırlık merkezlerinin vektörleri destek birimin ötesine geçerse denge bozulmaya başlar. Femur ve tibianin uzun ve silindirik yapıda, eklem yüzeylerinin yuvarlak yapıda olması bu noktada $9^{\circ}$ 'lik bir tolerans aralığı sağlar. Bu değerin ötesinde sistemin dengesi bozulur (Şekil 14). Kalçada iliofemoral, dizde ise posterior oblik bağlar, bağ desteği konusunda önde gelen yapılardır (Şekil 15).

Yürüyüş esnasında gövde destek bacağın arkasından önüne doğru, destek noktası ise topuk, ayak ortası ve ayak önü şeklinde ilerler. Sadece basma fazının ortasında, gövde stabil bir dizilime sahiptir. Yüklenmenin

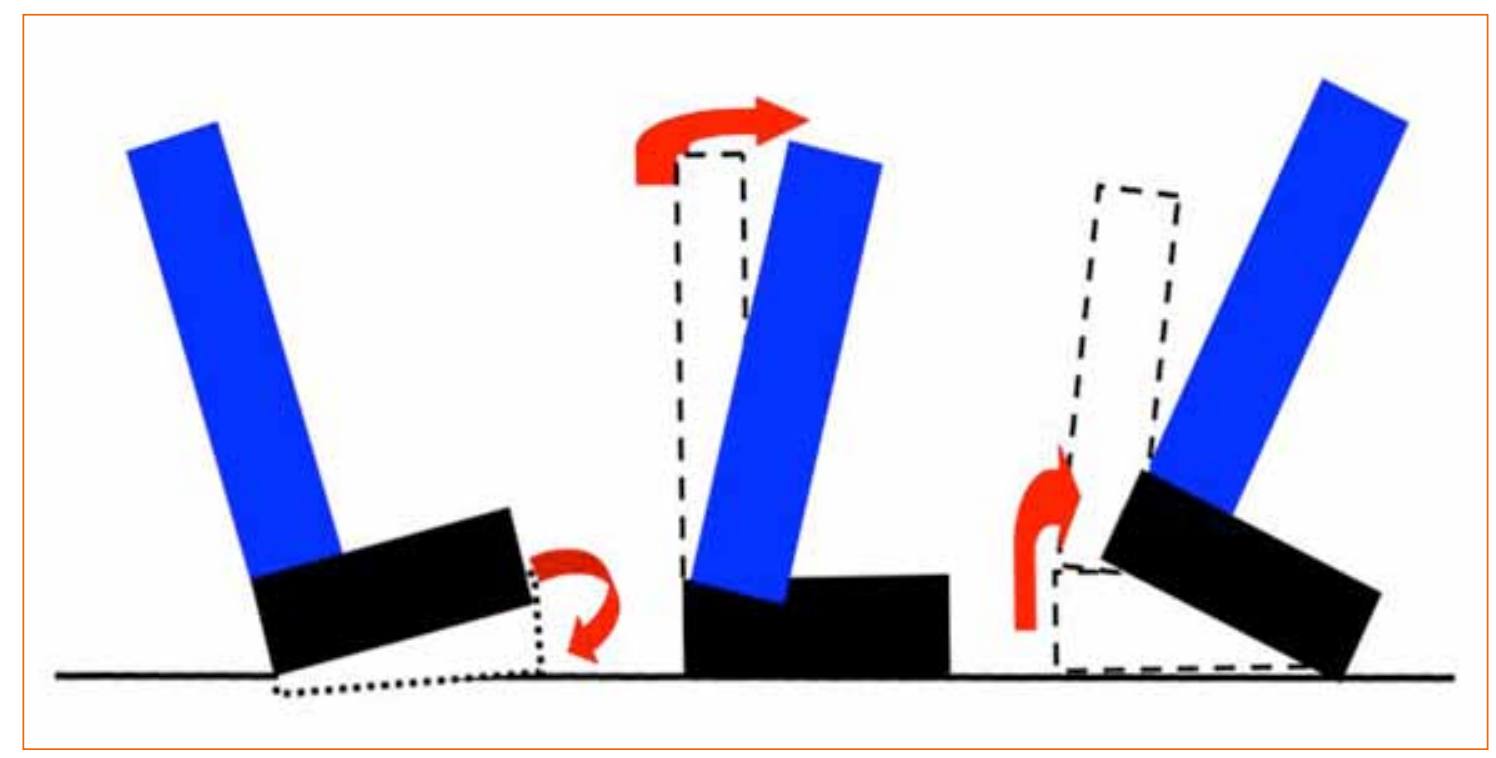

Şekil 13. Topuk, ayak bileği ve ön ayak vücut ağırlığının yüklenmesi ile destek tarafta beşik benzeri bir görev görür. 


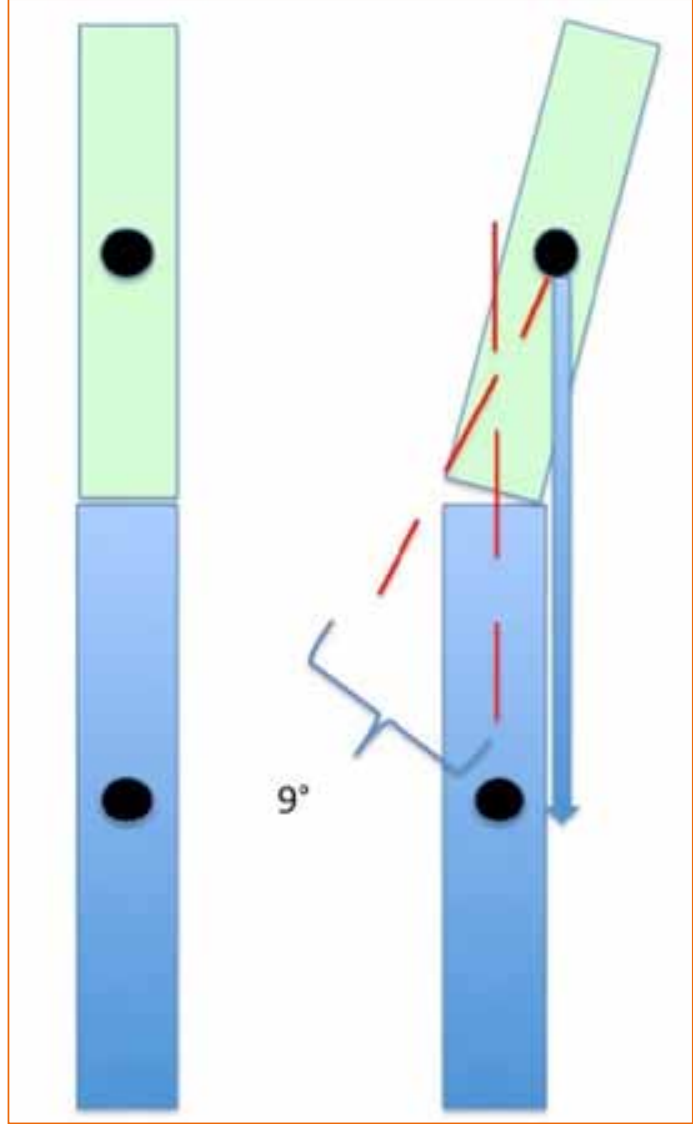

Şekil 14. Alt ve üst parçalar arasında $9^{\circ}$ 'lik tolerans aralığı vardır. Bu seviyenin ötesinde öne denge bozulur.

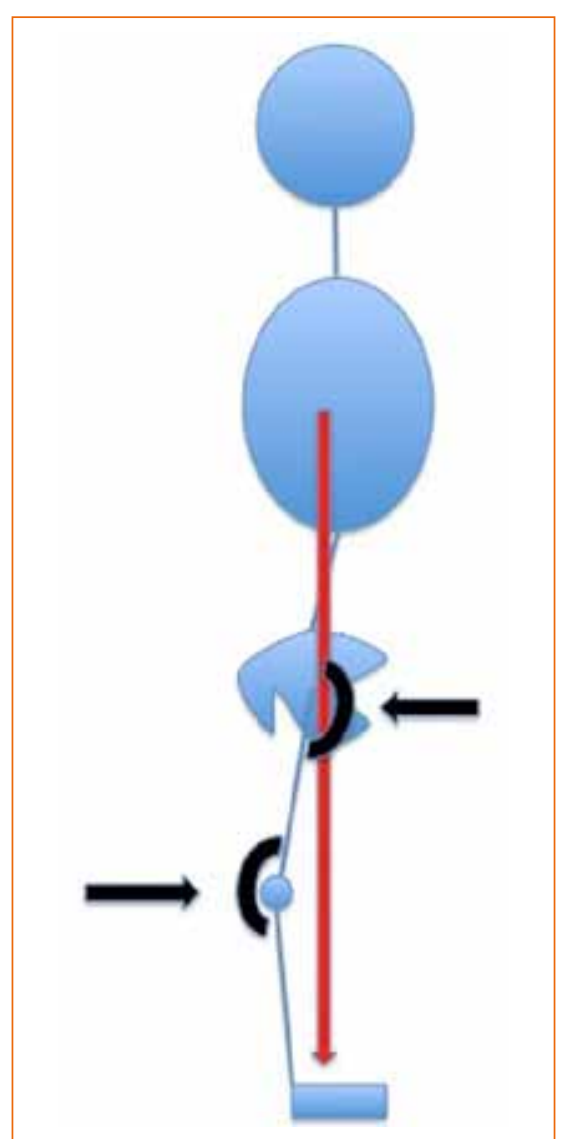

Şekil 15. Ayakta sabit duruşta kalça ve dizler hiperekstansiyona getirilerek pasif bir denge sağlanır. Dengenin sağlanmasında bağların önemi büyüktür. başında ayak gövdenin önünde yer alır. Gövdeye ait vektör kalçanın önünden, dizin arkasından geçer. Her iki kalçada fleksiyon torku oluşur. Vücudun düşmemesi için aktif kalça ekstansör kaslarının yanıtı gerekir. Duruş ortası fazında, gövde destek ayak üzerinde yer alır. Bu durumda fleksiyon torku sıfıra kadar düşer. Gövdenin ilerlemesi ile kalça ve dizler pasif ekstansiyona gelir. Bu durumda denge için plantar fleksörlerin aktif rol alması gerekir (Şekil 16).

3) Şok emilimi: Yürüyüş esnasında çok kısa bir dönemde, gövde serbest düşüş gerçekleştirir. Bu durum öndeki bacakta kısa süreliğine anormal bir yüklenmeye (vücut ağırlığının \%60'ı, 0,02 saniye kadar) yol açar. ${ }^{[19]}$ Zemine karşı olan bu darbe, ayak bileği, diz ve kalçada şok emilim yanıtı ile azaltılır. Basmanın ilk anı ile ayak bileğinin plantar fleksiyona getirilmesi, takip eden süreçte diz fleksiyonu ve sonrasında destek bacak tarafındaki abduktorların kasılmasıyla pelvisin düşmesinin engellenmesi, şok emiliminin üç basamağını oluşturur.
4) Enerji tasarrufu: Bu görev yukarıda açıklanmıştır. Pelvisin enerji harcamasını azaltmak, horizontal planda rotasyon, lateral deplasman ve karşı tarafa doğru eğilme ile sağlanır. Bu sayede, en az düzeyde enerji ile maksimum iş yapılmaya çalışıır.

\section{Koşma}

Son olarak, yürüme hızının artması sonucu oluşan "koşma" eyleminden bahsedelim: Koşma döngüsünde iki ayağın da yerle temas etmediği iki adet süzülme dönemi vardır (Şekil 17). Basma fazı kısalırken, salınım fazı uzar. Hızın artması ile basma fazı daha da kısalır. ileri gidebilmek için gerekli moment, yürümenin aksine basma fazındaki bacak yerine salınım fazındaki bacak ve kol tarafindan oluşturulur. Koşma esnasında, başta kalça ve diz fleksiyonu ile ayak bileği dorsifleksiyonu artar, ağırlık merkezinin yüksekliği azaltılır. Bunun yanında, diğer eklemlerin hareket açıklığı da artar. Bunu 


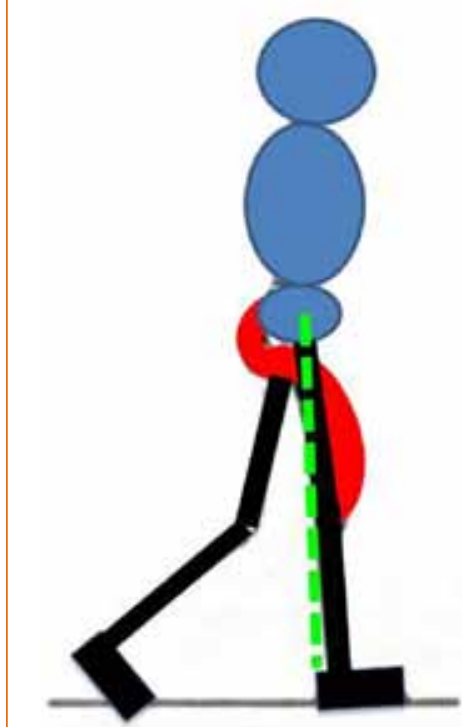

ilk yüklenme

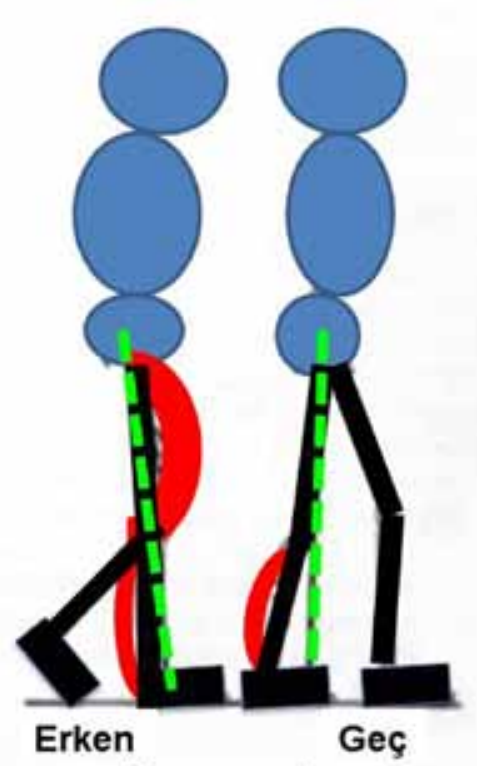

Basma ortası

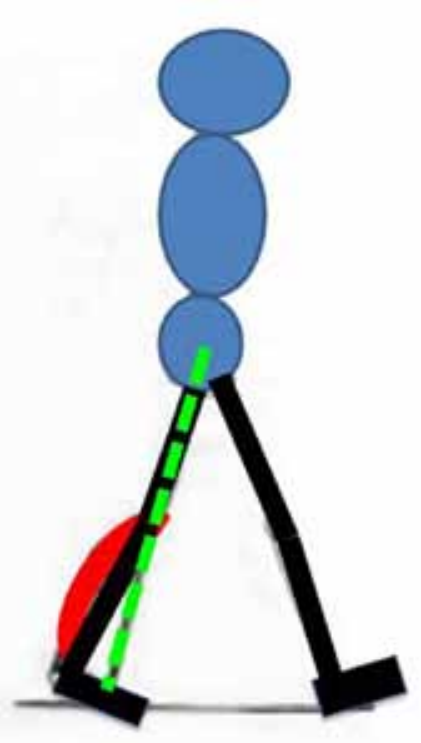

Basma sonu

Şekil 16. Yürüme esnasında dinamik denge, vücut ağırlığına ait vektörün eklemlere yönlendirilmesi ile düzenlenir. Basmanın erken döneminde, vektör kalçanın önünden, diz ve ayak bileği eklemlerinin arkasından, basma ortasının erken döneminde, dizin hafif arkasından, ayak bileğinin ise önünden geçer. Süreç devam ettikçe, vektör diz ve ayak bileği eklemlerinin önünden, kalçanın arkasından, basmanın sonunda ise kalçanın arkasından, diz ve ayak bileğinin önünden geçer. ${ }^{19]}$

(a)

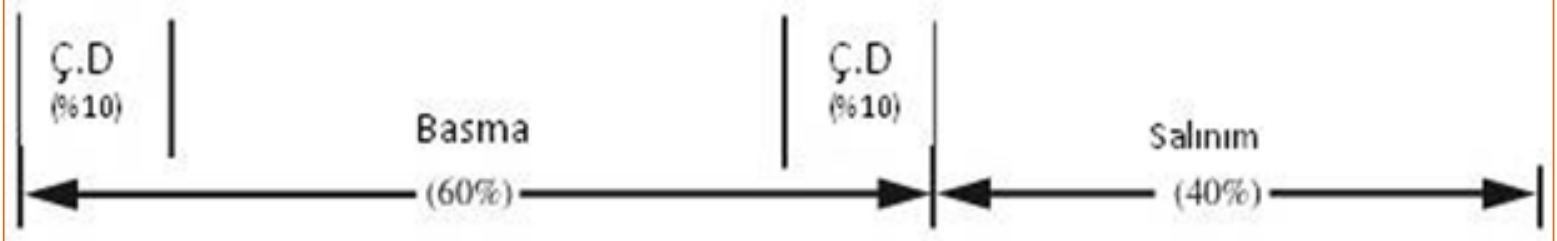

(b)

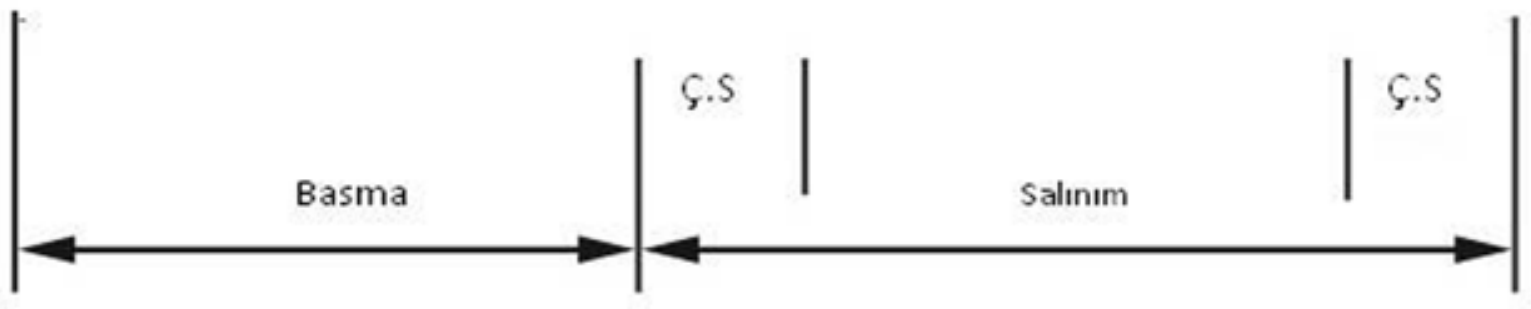

Şekil 17. a, b. Normal yürüyüşteki çift destek dönemi (Ç.D) (a) yerini koşma sırasında çift süzülme (Ç.S) dönemine bırakır (b).

karşılayabilmek için daha fazla kas kasılmasına ihtiyaç duyulur. ${ }^{[24,25]}$

Sonuç olarak, her ne kadar yürüme ve biyomekaniği ile ilgili birçok çalışma yapılmış olsa da, karmaşıklığı nedeniyle bire bir simülasyonu tam olarak yapılamamıştır. Bu nedenle çalışmalar hep basite indirgeme ile tamamlanabilmektedir. Ilerleyen teknoloji ve artan bilgi dağarcığı, bu karmaşık fonksiyonun daha iyi anlaşılabilmesi, buna bakarak anormal durumların tanınması ve tedavi edilmesinde önemli rol oynayacaktır. 


\section{KAYNAKLAR}

1. Ozkaya N, Nordin M. Fundamentals of Biomechanics: Equilibrium, Motion, and Deformation, 2nd ed. New York: Springer-Verlag; 1999.

2. Zajac FE, Neptune RR, Kautz SA. Biomechanics and muscle coordination of human walking. Part I: introduction to concepts, power transfer, dynamics and simulations. Gait Posture 2002;16(3):215-32.

3. Saunders JB, Inman VT, Eberhart HD. The major determinants in normal and pathological gait. J Bone Joint Surg Am 1953;35-A(3):543-58.

4. Kuo AD, Donelan JM, Ruina A. Energetic consequences of walking like an inverted pendulum: step-to-step transitions. Exerc Sport Sci Rev 2005;33(2):88-97.

5. Kuo AD. The six determinants of gait and the inverted pendulum analogy: A dynamic walking perspective. Hum Mov Sci 2007;26(4):617-56.

6. Rose J and Gamble JG, Human Walking, 3rd ed. Lippincott Williams \& Wilkins; 2006.

7. Whittle MW, Gait Analysis: An Introduction, 4th ed. Edinburgh, UK: Butterworth Heinemann; 2007.

8. Baker R. Clinical Gait Analysis. In: Winkelstein BA, editor. Orthopaedic Biomechanics. Taylor \& Francis Group; 2012. p.419-44.

9. Tiberio D, Gray GW. Kinematics and kinetics during gait. In: Donatelli R, Wooden MJ, editors. Orthopedic Physical Therapy. New York: Churchill Livingstone; 1989.

10. Donelan JM, Kram R, Kuo AD. Mechanical work for step-tostep transitions is a major determinant of the metabolic cost of human walking. J Exp Biol 2002;205(Pt 23):3717-27.

11. Della Croce U, Riley PO, Lelas JL, Kerrigan DC. A refined view of the determinants of gait. Gait Posture 2001;14(2):79-84.

12. Kerrigan DC, Riley PO, Lelas JL, Della Croce U. Quantification of pelvic rotation as a determinant of gait. Arch Phys Med Rehabil 2001;82(2):217-20.

13. Gard SA, Childress DS. The effect of pelvic list on the vertical displacement of the trunk during normal walking. Gait Posture 1997;5:233-8.
14. Gard SA, Childress DS. The influence of stance-phase knee flexion on the vertical displacement of the trunk during normal walking. Arch Phys Med Rehabil 1999;80(1):26-32.

15. Baker R, Kirtley C, Pandy M. Minimizing the energy cost of walking does not necessarily require minimizing the vertical excursion of the centre of mass. 8th International Symposium on the 3-D Analysis of Human Movement, Tampa, Florida, USA; 2004. p.101-4.

16. Zijlstra W, Hof AL. Displacement of the pelvis during human walking: experimental data and model predictions. Gait Posture 1997;6(3):249-62.

17. Cavagna GA, Heglund NC, Taylor CR. Mechanical work in terrestrial locomotion: two basic mechanisms for minimizing energy expenditure. Am J Physiol 1977;233(5):R243-61.

18. Lee CR, Farley CT. Determinants of the center of mass trajectory in human walking and running. J Exp Biol 1998;201(Pt 21):2935-44.

19. Perry J. Gait Analysis: Normal and Pathological Function. Thorofare, NJ: SLACK Incorporated; 1992.

20. LeVeau BF. Williams and Lissner Biomechanics of Human Motion, 2nd edition, Philadelphia, PA: WB Saunders Co.; 1977.

21. Karol LA. Gait Analysis. In: Herring JA, editor. Tachdjian's Pediatric Orthopaedics, 5th edition. Philadelphia, PA: Elsevier Saunders; 2014. p.71-8.

22. Mansour JM, Lesh MD, Nowak MD, Simon SR. A three dimensional multi-segmental analysis of the energetics of normal and pathological human gait. I Biomech 1982;15(1):51-9.

23. Mena D, Mansour JM, Simon SR. Analysis and synthesis of human swing leg motion during gait and its clinical applications. J Biomech 1981;14(12):823-32.

24. Mann RA. Biomechanics of running. In: Mack RP, editor. American Academy of Orthopaedic Surgeons Symposium on the Foot and Leg in Running Sports. St. Louis (MO): C.V. Mosby; 1982. p.1-29.

25. Dugan S, Bhat KP. Biomechanics and analysis of running gait. Phys Med Rehabil Clin N Am 2005;16(3):603-21. 